\title{
Use of the nursing process at public and private centers in a health area
}

\author{
Joseba Xabier Huitzi-Egilegor ${ }^{1}$ \\ Maria Isabel Elorza-Puyadena ${ }^{1}$ \\ Jose Maria Urkia-Etxabe ${ }^{2}$ \\ Jaime Zubero-Linaza ${ }^{3}$ \\ Xabier Zupiria-Gorostidi ${ }^{1}$
}

Aim: to analyze whether the nursing process method is used at public and private centers in the health area Gipuzkoa (Basque Country) and, if yes, to analyze in the framework of which model and how it is used. Method: cross-sectional study, based on the analysis of the nursing records used at the 158 centers studied. Results: the nursing process is applied at $98 \%$ of the centers. It is applied at all public and 18 out of 21 private centers. Virginia Henderson's model is the most used to apply it, and most centers use nursing diagnoses, the NIC-NOC terminology and standardized care plans. Conclusion: the use of the nursing process is widespread in Gipuzkoa, with greater use at public than at private centers.

Descriptors: Nursing Process; Nursing Diagnosis; Nursing Care; Models, Nursing.

\footnotetext{
${ }^{1}$ PhD, Full Professor, Departamento de Enfermería II, Escuela de Enfermería de Donostia-San Sebastián, Universidad del País Vasco - Euskal Herriko Unibertsitatea, Spain.

${ }^{2}$ PhD, Full Professor, Departamento de Física Teórica e Historia de la Ciencia, Universidad del País Vasco - Euskal Herriko Unibertsitatea, Spain.

${ }^{3}$ PhD, Assistant Professor, Departamento de Enfermería II, Escuela de Enfermería de Donostia-San Sebastián, Universidad del País Vasco - Euskal Herriko Unibertsitatea, Spain.
}

Corresponding Author:

Joseba Xabier Huitzi-Egilegor

Departamento de Enfermería II. Escuela de Enfermería de Donostia-San Sebastián

Universidad del País Vasco - Euskal Herriko Unibertsitatea

Paseo Doctor Beguiristain, 105

20014 Donostia-San Sebastián, España

E-mail: josebaxabier.huitzi@ehu.es 


\section{Uso do processo de enfermagem nos serviços públicos e privados de um distrito de saúde}

Objetivo: analisar se a metodologia do processo de enfermagem é utilizada nos serviços públicos e privados do distrito de saúde de Gipuzkoa (País Basco) e, caso seja, analisar sob qual modelo de enfermagem e de que maneira é utilizada. Método: estudo transversal, baseado na análise dos registros de enfermagem usados pelos 158 serviços estudados. Resultados: o processo de enfermagem aplica-se em $98 \%$ dos serviços estudados. É aplicado em todos os serviços públicos e em 18 dos 21 serviços privados. O modelo de Virginia Henderson é o mais utilizado para aplicá-lo, e o uso dos diagnósticos de enfermagem, da terminologia NOC-NIC e dos protocolos de cuidados padronizados é majoritário. Conclusão: conclui-se que o uso do processo de enfermagem está disseminado em Gipuzkoa, e que seu uso é maior nos serviços públicos do que nos privados.

Descritores: Processos de Enfermagem; Diagnóstico de Enfermagem; Cuidados de Enfermagem; Modelos de Enfermagem.

\section{Uso del proceso de enfermería en los centros públicos y privados de un área de salud}

Objetivo: analizar si la metodología del proceso de enfermería se utiliza en los centros públicos y privados del área de salud de Gipuzkoa (País Vasco) y, en caso de utilizarse, analizar bajo qué modelo enfermero y de qué manera se utiliza. Método: estudio transversal, basado en el análisis de los registros de enfermería que utilizan los 158 centros estudiados. Resultados: el proceso de enfermería se aplica en el $98 \%$ de los centros estudiados. Se aplica en todos los centros públicos y en 18 de los 21 centros privados. El modelo de Virginia Henderson es el más utilizado para aplicarlo, y el uso de los diagnósticos enfermeros, de la terminología NOC-NIC y de los planes de cuidados estandarizados es mayoritario. Conclusión: se concluye que el uso del proceso de enfermería está extendido en Gipuzkoa, y su uso es mayor en los centros públicos que en los privados.

Descriptores: Procesos de Enfermería; Diagnóstico de Enfermería; Atención de Enfermería; Modelos de Enfermería.

\section{Introduction}

The nursing process is the work method nursing uses in care delivery ${ }^{(1)}$. It consists of five phases: assessment, diagnosis, planning, implementation and finally evaluation.

Its creation dates back to the 1950-1960, in the United States and Canada. At that time, the idea started to gain force that, beyond isolated actions, nursing activities are part of a process ${ }^{(2)}$.

During the initial years, it was mainly discussed and developed in the teaching area. In the 1970's, its use was extended to clinical practice (professional practice), and the laws regulating health professionals' practice in the United States and Canada started to acknowledge that the use of the nursing process is one of the responsibilities of the nursing profession ${ }^{(3)}$.

Today, according to different reviews ${ }^{(4-5)}$, the nursing process method is used at health centers all over the world.

In Spain, studies show that the use of the nursing process starts to expand in the 1990 's(6-8) and that, nowadays, it is widespread ${ }^{(9)}$. There are few studies, however, which present concrete numerical data on its 
application. Among studies that do, one Spanish study should be highlighted(10), in which the establishment of the nursing process was analyzed at primary health care centers in Spain.

The aim in this research is to study whether this method is used at public and private health centers in Gipuzkoa (Basque Country). If yes, the intent is to analyze in the framework of which nursing model and how it is used. The results will provide knowledge on the way nursing works in Gipuzkoa.

\section{Method}

A cross-sectional study was developed (JanuaryDecember 2009), based on the analyzed of nursing records used at public and private centers in the health area Gipuzkoa, one of the three health areas in Basque Country.

In total, 158 centers were studied: 137 public (all public centers) and 21 private (all centers employing ten or more nursing professionals). At these 158 centers, 2667 nursing professionals are active (2103 at public and 564 at private centers), corresponding to about $90 \%$ of all professionals working in clinical practice in Gipuzkoa.

The criterion to determine whether the nursing process is applied or not at a given center is the existence of nursing records corresponding to the assessment phase of the nursing process, as subsequent phases are based on the first ${ }^{(1,11)}$. Therefore, if nursing assessment records are present, it is considered that the nursing process is applied; if not, it is not.

On the other hand, the criterion to determine that the nursing process is applied in the framework of a specific nursing model was to observe that, in the elaboration of the nursing assessment records, the guidelines of that model are followed.

Authorization from the management at the centers involved was obtained before getting access to the nursing records. The centers' anonymity was preserved in the publication of data.

The Research Ethics Committee at Universidad del País Vasco - Euskal Herriko Unibertsitatea (UPV-EHU) started to function in 2010. As data for this study were collected in 2009, getting ethical clearance from that committee was not possible.

Data were subject to quantitative analysis, using descriptive statistics.

\section{Results}

In 155 out of 158 centers under analysis, the nursing process is applied. Hence, the nursing process is applied at $98 \%$ of the centers studied. It is applied at all public and 18 out of 21 private centers.

Nevertheless, at many of the centers where we considered that the nursing process is applied, its use has not been extended to all services. To give an example, at public specialized care centers, it is used at most services (traumatology, cardiology, nephrology, general surgery...), but not at the intensive care unit, operating rooms, recovery, emergency, radiology, delivery and neonatal services. In another example, at public primary care centers, it is used in nursing consultations, first aid and home care, but not in midwifery and pediatric consultations nor in the emergency service.

In Table 1, it is shown what centers were studied, the number of nursing professionals working at the centers and at the services where the nursing process is applied.

Table 1 - Centers studied, number of nursing professionals working at the centers and at the services where the nursing process (NP) is applied

\begin{tabular}{lccc}
\hline \multicolumn{1}{c}{ Health system and area } & Centers & No. of nursing prof. & $\begin{array}{c}\text { No. of nursing prof. at services } \\
\text { that apply the NP }\end{array}$ \\
\hline Public health system & 137 & 2103 & 1543 \\
Primary care & 116 & 514 & 411 \\
Specialized care & 5 & 1523 & 1066 \\
Hospital No. 1 & 1 & 1072 & 750 \\
Hospital No. 2 & 1 & 110 & 77 \\
Hospital No. 3 & 1 & 111 & 78 \\
Hospital No. 4 & 1 & 143 & 100 \\
Hospital No. 5 & 1 & 87 & 61 \\
Mental health & 15 & 54 & 54 \\
Psychiatry service at Hospital No. 1 & 1 & 22 & 22 \\
Outpatient care centers & 14 & 32 & 32
\end{tabular}


Table 1 - (continuation)

\begin{tabular}{lccc}
\hline Health system and area & Centers & No. of nursing prof. & $\begin{array}{c}\text { No. of nursing prof. at services } \\
\text { that apply the NP }\end{array}$ \\
\hline Gerontology-geriatrics & 1 & 12 & 12 \\
Private health system & 21 & 564 & 214 \\
Specialized care & 6 & 410 & 60 \\
Hospital No. 1 & 1 & 35 & 0 \\
Hospital No. 2 & 1 & 85 & 0 \\
Hospital No. 3 & 1 & 40 & 25 \\
Hospital No. 4 & 1 & 50 & 25 \\
Hospital No. 5 & 1 & 165 & 0 \\
Hospital No. 6 & 1 & 35 & 10 \\
Mental health & 4 & 69 & 69 \\
Hospital No. 1 & 1 & 25 & 25 \\
Hospital No. 2 & 1 & 22 & 22 \\
Hospital No. 3 & 1 & 12 & 12 \\
Hospital No. 4 & 1 & 10 & 10 \\
Gerontology-geriatrics & 11 & 85 & 85 \\
Geriatric center No. 1 & 8 & 55 & 55 \\
Geriatric center No. 2 & 1 & 10 & 10 \\
Geriatric center No. 3 & 1 & 10 & 10 \\
Geriatric center No. 4 & 1 & 10 & 10 \\
\hline
\end{tabular}

According to the figures in Table 1 , the number of nursing professionals working at the services where the nursing process is applied represents $66 \%$ of nursing professionals working at the centers under analysis. They represent $73 \%$ of professionals at public and $38 \%$ at private centers.

Concerning the nursing model used to apply the nursing process, out of 155 centers, Virginia Henderson's

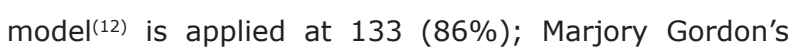
conceptual structure ${ }^{(13)}$ at $17(11 \%)$; and the RAI-NH 2.0 (Resident Assessment Instrument Nursing Home $2.0)^{(14)}$ at one. At the remaining four centers, the nursing process is applied without the support of any model or conceptual structure, and records are elaborated at the criterion of nursing professionals working at each center.

As for the nursing diagnoses, these are used at 148 (95\%) out of 155 centers applying the nursing process. In quantitative terms, professionals working at services where nursing diagnoses are used represent $61 \%$ of nursing professionals working at the centers studied. In all cases, the NANDA-I ${ }^{(15)}$ criteria are used to reach the diagnoses.

What the NIC-NOC terminology is concerned ${ }^{(16-17)}$, it is used at 124 ( $80 \%)$ out of 155 centers applying the nursing process. In numbers, professionals working at services where the NIC-NOC terminology is used represent $57 \%$ of nursing professionals working at the centers studied.

Other relevant results are related to the use of standardized care plans and the computerization of the nursing process. Standardized care plans are used at $127(82 \%)$ of the 155 centers that apply the nursing process, and 142 (92\%) out of 155 centers have computerized the records of data related to the nursing process.

\section{Discussion}

The results related to the number of centers applying the nursing process are in accordance with the reviews found ${ }^{(4-5)}$. These reviews state that the nursing process is widespread among centers all over the world. Our study reveals that this is also the case at almost all centers in Gipuzkoa.

In comparison with related studies, the figures obtained in our research are higher than in another Spanish study, which indicates that $43 \%$ of health centers apply the nursing process in primary health care $^{(10)}$.

On the other hand, it is noteworthy that the use of the nursing process is more widespread at public than at private centers. One reason can be that, in Spain, the public health system has received more human and material resources than the private system ${ }^{(18)}$. The more resources are available, the easier it becomes to put in practice new work methods.

When considering the data per activity area, in mental health and gerontology-geriatrics, the nursing process is applied at all centers and services (both public and private). In primary and specialized care, on the other hand, it is not always used. This can be related 
to the length of the patient's stay in each area. Mental health and gerontology-geriatrics patients are medium or long-term patients, which grants nurses a greater margin to act and apply the nursing process. In primary and specialized care, on the other hand, many patients are short-term, making it difficult for the nurse to apply the nursing process.

The results related to the nursing model used to apply the nursing process show that, in Gipuzkoa, Virginia Henderson's model(12) is the most used to apply the nursing process. In addition, considering that neither Marjory Gordon's ${ }^{(13)}$ conceptual structure nor the RAI-NH 2.0 structure (Resident Assessment Instrument Nursing Home 2.0)(14) are nursing models, but assessment structure(13-14), we could say that Virginia Henderson's is the only nursing model used in Gipuzkoa.

This is in line with other studies developed in Spain ${ }^{(10,19)}$, showing that Henderson's model is the most used. Also, this is in accordance with global practices, as different authors conclude that Henderson's model is one of the best known and used models globally(20-21).

Anyway, the figures obtained in our study are higher than findings in other similar studies. In a study developed in Canada, only $25.5 \%$ of the centers use a nursing model to apply the nursing process ${ }^{(22)}$. In a study developed in Spain, it is affirmed that, in primary care, $35 \%$ of the centers use a nursing model(10). In the latter, Virginia Henderson's(12) is the most frequent model.

Except two, all centers using Marjory Gordon's conceptual structure(13) belong to the mental health sector. This can be due to the fact that the school in Basque Country that offers the specialization program in mental health nursing has elected this structured.

As for the results related to the use of the nursing diagnoses, in all cases, the NANDA-I criteria were used to elaborate these. That is in line with the international reality, as observed in a review ${ }^{(4)}$. On the other hand, these results on the use of diagnoses cannot be compared with others as, although some studies affirm that the use of nursing diagnoses is widespread in Spain ${ }^{(8,10)}$ and around the world(3), no numerical data are provided on their use.

Findings on the number of centers that have computerized the nursing process is positive as, according to one study(23), computerization enhances information quality, interprofessional communication and nursing activity measures.

Besides analyzing in the framework of what nursing model and how it is used, future studies could look at the coherence in the completion of nursing process records, which has already been done in other places ${ }^{(4,24-26)}$.

\section{Conclusions}

These study results offer concrete numerical data on the application of the nursing process and show that, like in the rest of the world, the use of the nursing process is widespread in Gipuzkoa, with higher levels at public than at private centers.

As for the nursing model used, this study reveals that, in Gipuzkoa, Virginia Henderson's model is the most used nursing model to apply the nursing process.

Finally, this research reveals that the nursing diagnoses, the NOC-NIC terminology and standardized care plans are a reality at most centers.

\section{References}

1. Alfaro-Lefevre R. Applying nursing process: promoting collaborative care. Philadelphia: Lippincott; 2002.

2. De la Cuesta $C$. The Nursing Process: from development to implementation. J Adv Nurs. 1983;8:365-71.

3. Lavin MA, Meyer G, Carlson JH. A review of the use of nursing diagnosis in U.S. Nurse Practice Acts. Nurs Diag. 1999;10(2):57-64.

4. Müller-Staub M, Lavin MA, Needham I, Van Achterberg

T. Nursing diagnoses, interventions and outcomes application and impact on nursing practice: systematic review. J Adv Nurs. 2006;56(5):514-31.

5. Lunney M. Critical thinking and accuracy of nurses diagnosis. Int J Nurs Terminol Classif. 2003;14(3):96-107. 6. García-Carpintero J, Piñón M. ¿Por qué no siempre funciona el PAE? Rol Enferm. 1994;195:63-6.

7. Martín E, García F, Asenjo A. Diagnósticos de enfermería. Estrategias de implantación. Rol Enferm. 1997;225:57-63.

8. Cuesta A, Luis MT, González P, Germán C, Coscollá E, Benavent MA, Palomino PA, Sales R, Guirao JA. El diagnóstico de enfermería en España, ¿una realidad apreciable?. Index Enferm (edición digital) 1995; [acesso 21 maio 2011];12-13. Disponivel em: http:// www.index-f.com/index-enfermeria/12-13/1423.php.

9. González MA. Normalización de la práctica enfermera como contribución a la salud, la calidad asistencial y la seguridad clínica de las personas (tesis doctoral). Madrid: Consejo General de Colegios Oficiales de Enfermería de España; 2006.

10. Izquierdo JM, Pérez MB, Ramírez FJ, Serrano I, Torres MD, Conde G. Implantación del proceso enfermero. Rol Enferm. 2002;25(7-8):488-93.

11. Giménez AM, Serrano P. Imprecisiones del proceso diagnóstico enfermero. Metas Enferm. dic 2008/ene 2009;11(10):57-62. 
12. De Henderson VA. The nature of nursing: Reflections after 25 years. New York: National League for Nursing Press; 1991.

13. Gordon M. Nursing diagnosis: process and application. 3 ed. St. Louis: Mosby; 1994.

14. Morris JN, Hawes C, Fries BE, Phillips CD, Mor V, Katz S, Murphy K, Drugovich ML, Friedlob AS. Designing the national resident assessment instrument for nursing homes. The Gerontologist. 1990;30(3):293-307.

15. NANDA-International. Nursing diagnoses. Definitions and classification 2012-2014. Oxford: Wiley-Blackwell; 2012.

16. Moorhead $S$, Johnson $M$, Maas $M L$, Swanson $E$. Nursing outcomes classification (NOC). 5 ed. St. Louis: Elsevier Health Sciences; 2012.

17. Bulechek GM, Butcher HK, Dochterman JM, Wagner C. Nursing interventions classification (NIC). 6 ed. St. Louis: Elsevier Health Sciences; 2012.

18. De Manuel E, De Oleaga JI. Sistemas de salud en los países desarrollados. In: Martín Zurro A, Cano Pérez JF, editors. Atención Primaria. Conceptos, organización y práctica clínica. 5 ed. Madrid: Elsevier; 2003. p. 16-46.

19. Catalina MR. Las bases de la enfermería actual. Educare. 2007;21:41.

20. Marriner A, Raile M. Nursing theorists and their work. 6.ed. New York: Mosby/Elservier; 2006.

21. Luis MT, Navarro MV, Fernández C. De la teoría a la práctica: el pensamiento de Virginia Henderson en el Siglo XXI. 3 ed. Barcelona: Masson; 2005.

22. Simpson J, Taylor D. Reality check. Do conceptual models of nursing work today?. Can Nurse. 2002 Feb;98(2):24-6.

23. Urquhart $C$, Currell $R$, Grant MJ, Hardiker NR. Nursing record systems: effects on nursing practice and healthcare outcomes. Cochrane Database of Systematic Reviews 2009; [acesso 22 set 2011]; Issue 1. Art. No.: CD002099. DOI: 10.1002/14651858.CD002099. pub2. Disponivel em:http://onlinelibrary.wiley.com/ doi/10.1002/14651858.CD002099.pub2/pdf/abstract 24. García R, Martínez E, Amal R, Cañada A. Trabajar con método científico. Rol Enferm. ene 2004;27(1):15-8.

25. Frómeta $M$, Alba M, Momblanch D, Hernández I. Modo de actuación en proceso de enfermería. Rev Cubana Enferm. 2000;16(2):101-5.

26. Pokorski S, Moraes MA, Chiarelli R, Rabelo E. Nursing process: from literature to practice: what are we actually doing? Rev. Latino-Am. Enfermagem. 2009 May-June;17(3):302-7. 